\title{
Sukuk and Bond Performance in Malaysia
}

\author{
Fadma El Mosaid ${ }^{1} \&$ Rachid Boutti ${ }^{2}$ \\ ${ }^{1}$ National School of Applied Sciences, Ibn Zohr University, Agadir, Morocco \\ ${ }^{2}$ National School of Business and Management, Ibn Zohr University, Agadir, Morocco \\ Correspondence: Fadma El Mosaid, National School of Applied Sciences, Ibn Zohr University, PO box 1136, \\ Agadir 80000, Morocco. Tel: 212-528-228-313. E-mail: f.elmosaid@gmail.com
}

Received: November 28, 2013

Accepted: December 20, 2013

Online Published: January 23, 2014

doi:10.5539/ijef.v6n2p226

URL: http://dx.doi.org/10.5539/ijef.v6n2p226

\begin{abstract}
Sukuk and bonds are two kinds of financial instruments that share the Malaysian capital market. Sukuk are Sharia-compliant financial instruments referred as "Islamic bonds" in the Malaysian market (Note 1). The aim of this paper is to diagnose the performance of Sukuk portfolios compared with bond portfolios. For this purpose, we use the series of indices TR BPAM ALL BOND INDEX. Those indices cover the whole Sukuk and bond Malaysian market. We collect historical data of those indices from the website of Bond Pricing Agency of Malaysia (BPAM) for a period of six years from 2007 to 2012. We first study the significance of the difference in the portfolios' mean return. Secondly, we address the portfolios' return correlation. Comparing indices shows that Sukuk index outperformed the bond index and market index. Furthermore, the results confirm a significant and positive correlation between returns of Sukuk and bond portfolios.
\end{abstract}

Keywords: sukuk, bond, portfolio, return, t-test, correlation

\section{Introduction}

Sukuk is an Arabic term; it is a plural of term Sack which means certificate. The term Sukuk is, broadly, translated as "Islamic bonds" although the correct translation is "Islamic Investment Certificates" (Tahmoures, 2013). The Accounting and Auditing Organization for Islamic Financial Institutions (AAOIFI) officially defined Sukuk as certificates of equal value representing undivided shares in ownership of tangible assets, usufruct and services (AAOIFI, 2008). Referring Sukuk as "Islamic bonds" is due to some similarities between Sukuk and bonds, especially in terms of financial process. In fact, some studies say that Sukuk are innovated to mimic the financial features of bonds in addition to being compliant with Islamic finance principles, we cite for example the work of Lahsasna and Lin (2012).

In fact, several similarities exist between Sukuk and bonds; however these two financial instruments are different and are not duplicate tools of financing. Like conventional bonds, Sukuk have fixed term maturity, coupon and are tradable at normal yield price (Zakaria, Isa, \& Abidin, 2012). Unlike bonds, Sukuk are issued in accordance with Sharia principles. Indeed, Sukuk differ from conventional bonds since bonds are defined as long-term debt instruments that are issued by corporations and government (Tahmoures, 2013) while Sukuk are defined by AAOIFI (2008) as certificates of equal value that represent proportion ownership of an existing asset or a pool of diversified assets.

Despite the debate on various aspects of Sukuk such as their originality, their compliance and their performance, Sukuk have become promising alternative instruments of financing consistent with portfolio theory and financial planning. Financial engineering has implemented several Sukuk structures to enable public and private organizations to fund. Furthermore, investors can include Sukuk in their portfolios as part of their portfolio diversification strategies (Oakley, 2011).

The Sukuk market is the fastest growing and promising segment of Islamic finance. Indeed, the issuance of Sukuk is increasing considerably worldwide, especially in Malaysia, United Arab Emirates (UAE) and Saudi Arabia (Fitriya, 2012). The global value of Sukuk issues exceeds 109 billion dollars in 2012 (Figure 1).

Malaysian Sukuk market is among the most structured in the field. The first issues of Sukuk date 90s with the corporate Sukuk issued by Shell MDS (Note 2). The volume of this issue around 30 million dollars. The Sukuk market is held in parallel with the conventional bond market. 
The remarkable success of the Sukuk market in Malaysia (Figure 2) is largely due to the regulation imposed by the Central Bank of Malaysia (Bank Negara Malaysia) (Thomas, 2007). However, Malaysia is facing increased competition from other countries in the region such as Indonesia, Singapore and other countries in addition to the Middle East and the Gulf as the UAE, Bahrain and Saudi Arabia.

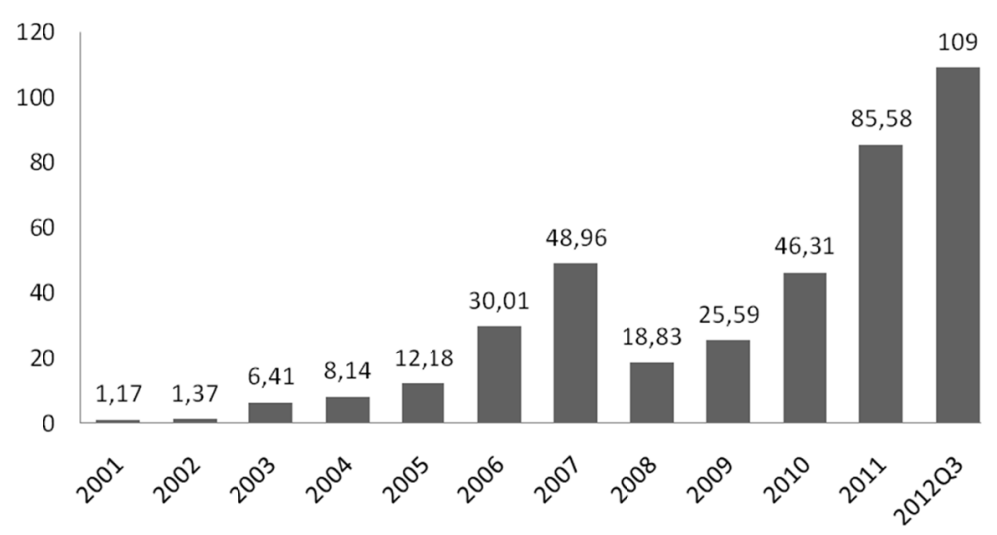

Figure 1. Evolution of Sukuk global issues between 2001 and 2012 in billion \$

Malaysia is the first country and the most dynamic to issue Sukuk and emerged as a global pioneer in Sukuk with $67 \%$ of the total volume of issues between 2009 and 2012 (Figure 2).

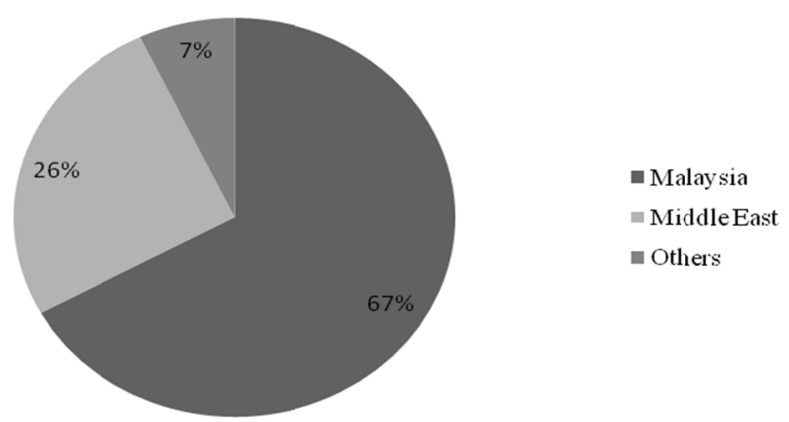

Figure 2. Volume of Sukuk issues by region between 2009 and 2012

The remainder of the paper is organized as follows. Section 2 provides a brief background on recent researches on Sukuk. Section 3 highlights the research method and data. Section 4 discusses the findings and the final section concludes the paper.

\section{Literature Review}

Several studies attempt to compare Sukuk and conventional bonds in term of their structure, their properties and how the market perceives them as different investment alternatives such as researches (Cakir \& Raei, 2007; Ramasamy, Munisamy, \& Helmi, 2011; Zin et al., 2011; Ariff \& Safari, 2012; Hassan, 2012; Lahsasna \& Lin, 2012; Fathurahman \& Fitriati, 2013; Godlewski, Turk-Arsis, \& Weill, 2013; Tahmoures, 2013).

Cakir and Raei (2007) conducted their work on the Value at Risk (VaR) of a portfolio of fixed income securities with a sample of Sukuk and Eurobonds issued by the same sovereign issuer. In their study, the authors constructed two hypothetical portfolios, the first consists only of Eurobonds and the other consists of both Eurobonds and Sukuk. Cakir and Raei (2007) concluded that the Sukuk reduce the VaR of the second portfolio. Ramasamy et al. (2011) compared Sukuk to government bonds and conventional bonds in Malaysian market in terms of sensitivity using duration and convexity measures. The results indicated that Sukuk are better in these sensitivity measures when compared with conventional bonds. The findings of Ramasamy et al. (2011) confirmed that Sukuk are less risky than conventional bonds and that the investors on Sukuk will obtain a better yield rate when compared to government bonds and lesser rate than conventional bonds. 
Zin et al. (2011) attempted to explore the practice and prospect of Sukuk market in Malaysia and discuss the difference between Sukuk and conventional bonds in Malaysian market. The authors confirmed the advantages and the value added offered by the Islamic capital market of Sukuk. Indeed, Sukuk are now promising tools for financing and for investors.

Ariff and Safari (2012) examined the deference between Sukuk and conventional bonds by investigating the presence of a causal link between the performance on Sukuk and conventional bonds with the same yield and the same rating. Their results found no causal link.

Hassan (2012) conducted his research on the comparison of Sukuk and bonds in assessing any differences related to the diversification of bonds portfolios by adding Sukuk. The author assessed the value at risk (VaR) of Sukuk compared with VaR of conventional bonds of the same issuer. The results highlighted that there is a gain in diversification of bonds portfolios by adding Sukuk. In addition, Hassan (2012) stressed that Sukuk portfolio is riskier than a bond portfolio. This may be due to factors related to characteristics of Islamic finance.

Lahsasna and Lin (2012) focused on Sukuk Sharia issues considering that structuring Sukuk mimics features of conventional bonds in Malaysian market such as in terms of late payment penalty, trading of debt based Sukuk, purchase undertaking in equity based structures and ownership status in asset based transactions. These issues pose a Sharia debate which is extended to other financing practices in Islamic finance.

Fathurahman and Fitriati (2013) attempted to analyze the ratio between yields (yield to maturity [YTM]) on Sukuk and conventional bonds listed in Indonesian stock market in October 2011. The findings showed that the average of the Sukuk and conventional bonds differs significantly overall and that Sukuk average YTM is greater than conventional bonds in three of ten groups studied. The authors concluded their paper by recommending the consideration of compliance with Sharia in future researches.

Godlewski et al. (2013) investigated the reaction of Malaysian market investors to the announcements of Sukuk and conventional bonds issues. The stock market is neutral to announcements of conventional bond issues, but it reacts negatively to announcements of Sukuk issues. Godlewski et al. (2013) assigned this result to the great demand for Islamic investment certificates and to the adverse selection promoting Sukuk issuance by lower-quality debtor firms.

Tahmoures (2013) addressed the issue of compatibility between Sukuk and conventional bonds. The author attempted to compare these two financial instruments from different points of view like the structure and risk/return features. Tahmoures (2013) supported that issuers and investors can choose one or other of these financial instruments since Sukuk and bonds succeed in raising capital for both corporations and governments. Nevertheless, there are basic differences between the two instruments. Indeed, bonds are based on debt while Sukuk are equity based instruments. Then Sukuk are ideal choice for investors wishing to respect the Islamic finance principles.

Most publications as Cakir and Raei (2007), Ariff and Safari (2012), Hassan (2012) and Godlewski et al. (2013) agree that Sukuk offer an alternative investment, but the debate about if Sukuk is an efficient instrument of investment is always open.

Our aim in this paper is to analyze the performance of Sukuk portfolios and bond portfolios in Malaysian bonds and Sukuk market by using the series of indices TR BPAM ALL BOND INDEX rather than individual Sukuk or bonds. Indeed, this series of indices represent the whole Malaysian bonds and Sukuk market and allow to illustrate the global performance of this market.

\section{Data and Methodology}

\subsection{Research Questions}

Our research questions for this study are:

Q1: "Does the Sukuk portfolios return differ significantly from conventional bonds portfolios return?"

Q2: “Are there a correlation between the return of portfolios of Sukuk and bonds portfolios?"

\subsection{Data Sample of the Study}

The data used in purpose of this study are daily historical data of TR BPAM ALL BOND INDEX obtained through Bond Pricing Agency Malaysia (BPAM) website. This series of indices was created in 2007 by Thomson Reuters and the Malaysian Bond Pricing Agency (BPAM). These indices are very representative of the Malaysian Sukuk and bonds market hence our choice of those indices in the context of this study. 


\subsection{Methodology}

Our purpose is to evaluate the performance of Sukuk portfolios compared with conventional bonds portfolios in the context of Malaysian market. For this purpose, we create our portfolios using the indices of the series TR BPAM $A L L$ BOND INDEX in Malaysian bonds and Sukuk market (Table 1). Furthermore, we use the global index TR BPAM ALL BOND INDEX as a benchmark of the global market.

For Sukuk, we use the Islamic segment of the index TR BPAM ALL BOND INDEX and to represent bonds we use the conventional segment of the index. For each maturity, we take the appropriate segment of the index.

For example:

- Sukuk portfolio of all maturities $\mathrm{P} 1_{\text {Sukuk(all) }}$ is corresponding to index TR BPAM ALL BOND INDEX-Islamic-All maturities.

- Sukuk portfolio of 3 months to one year of maturity is corresponding to index TR BPAM ALL BOND INDEX-Islamic-3months to 1 year of maturity.

- Bonds portfolio of 1 year to three years of maturity is corresponding to index TR BPAM ALL BOND INDEX-Conventional- 1year to 3 years of maturity.

- Bonds portfolio of more than 7 years of maturity is corresponding to index TR BPAM ALL BOND INDEX-Conventional- 7+year of maturity.

Islamic indices represent Sukuk portfolios and conventional indices represent conventional bonds portfolios. The composition of every index is given in Table 1. This table indicates the number of Sukuk and bonds in each index between 2007 and 2012.

Table 1. Sukuk and bonds portfolios and corresponding indices

\begin{tabular}{|c|c|c|c|c|c|c|c|}
\hline Portfolio & Corresponding index & 2007 & 2008 & 2009 & 2010 & 2011 & 2012 \\
\hline$P 1_{\text {Sukuk(all) }}$ & TR BPAM ALL BOND INDEX-Islamic-All maturities & $450 \mathrm{~S}$ & $499 \mathrm{~S}$ & $522 \mathrm{~S}$ & $525 \mathrm{~S}$ & $571 \mathrm{~S}$ & $621 \mathrm{~S}$ \\
\hline $\mathrm{P} 1_{\text {Bonds(all) }}$ & TR BPAM ALL BONDS INDEX-Conventional-All maturities & 200B & 189B & 191B & 207B & 197B & 198B \\
\hline $\mathrm{P} 2_{\text {Sukuk }(3 \mathrm{~m}-1 \mathrm{y})}$ & TR BPAM ALL BOND INDEX-Islamic- 3months to 1 year of maturity. & $35 \mathrm{~S}$ & $39 \mathrm{~S}$ & $42 \mathrm{~S}$ & $46 \mathrm{~S}$ & $42 \mathrm{~S}$ & $43 \mathrm{~S}$ \\
\hline $\mathrm{P} 2_{\text {Bonds }(3 \mathrm{~m}-1 \mathrm{y})}$ & TR BPAM ALL BOND INDEX-Conventional- 3months to 1 year of maturity. & $35 \mathrm{~B}$ & 30B & $31 \mathrm{~B}$ & 27B & $31 \mathrm{~B}$ & $34 \mathrm{~B}$ \\
\hline $\mathrm{P} 3_{\text {Sukuk }(1 \mathrm{y}-3 \mathrm{y})}$ & TR BPAM ALL BOND INDEX-Islamic- 1 year to 3 years of maturity. & $97 \mathrm{~S}$ & $105 \mathrm{~S}$ & $101 \mathrm{~S}$ & $111 \mathrm{~S}$ & $121 \mathrm{~S}$ & $114 \mathrm{~S}$ \\
\hline $\mathrm{P} 3_{\text {Bonds }(1 \mathrm{y}-3 \mathrm{y})}$ & TR BPAM ALL BOND INDEX-Conventional- 1 year to 3 years of maturity. & $68 \mathrm{~B}$ & 63B & $64 \mathrm{~B}$ & $79 \mathrm{~B}$ & $75 \mathrm{~B}$ & $67 \mathrm{~B}$ \\
\hline $\mathrm{P} 4_{\text {Sukuk }(3 \mathrm{y}-7 \mathrm{y})}$ & TR BPAM ALL BOND INDEX-Islamic- 3 years to 7 years of maturity. & $160 \mathrm{~S}$ & $167 \mathrm{~S}$ & $183 \mathrm{~S}$ & $182 \mathrm{~S}$ & $179 \mathrm{~S}$ & $176 \mathrm{~S}$ \\
\hline $\mathrm{P} 4_{\text {Bonds(3y-7y) }}$ & TR BPAM ALL BOND INDEX-Conventional- 3 years to 7 years of maturity. & $71 \mathrm{~B}$ & 67B & $62 \mathrm{~B}$ & $65 \mathrm{~B}$ & $62 \mathrm{~B}$ & $65 \mathrm{~B}$ \\
\hline $\mathrm{P} 5_{\text {Sukuk }(7 y+)}$ & TR BPAM ALL BOND INDEX-Islamic- 7 years and more maturity. & $168 \mathrm{~S}$ & $187 \mathrm{~S}$ & $197 \mathrm{~S}$ & $186 \mathrm{~S}$ & $229 \mathrm{~S}$ & $289 \mathrm{~S}$ \\
\hline P5 $5_{\text {Bonds }\left(7 y^{+}\right)}$ & TR BPAM ALL BOND INDEX-Conventional- 7 years and more of maturity. & 27B & 28B & $34 \mathrm{~B}$ & $35 \mathrm{~B}$ & 29B & $32 \mathrm{~B}$ \\
\hline
\end{tabular}

The Table 1 above gives the indices used to represent different Sukuk and bonds portfolios. In addition, Table 1 indicates the number of Sukuk or bonds for each index between 2007 and 2012. For example, the first line corresponding to Sukuk index of all maturities indicates that the index contain 450 Sukuk (450S) in 2007, 499 Sukuk in 2008 and 621 Sukuk in 2012. The corresponding conventional index is composed of 200 bonds (200B) in 2007, 189 bonds in 2008 and 198 bonds in 2012.

We construct our portfolios using these indices. For instance, the first portfolio $\mathrm{P} 1_{\text {Sukuk(all) }}$ corresponds to the index TR BPAM ALL BOND INDEX-Islamic-All maturities which comprises Sukuk of all maturities. The number of Sukuk varies between 450 in 2007 and 621 in 2012.

We obtained five Sukuk portfolios and five bonds portfolios. We use the paired sample t-test for means to address the first research question Q1 and we use the Pearson correlation tests to answer the second research question Q2.

\section{Empirical Results and Discussion}

\subsection{Sample Characteristics}

Figure 3 indicates the evolution of Sukuk, bonds and market indices from the series TR BPAM ALL BOND INDEX in Malaysian Sukuk and bonds market. Over the entire period from 2007 to 2012, the three indices move in the 
same direction. From 2007 to mid-2008 the three indices are almost identical. From mid 2008 to 2009 indices take their growth after a fall in mid-2008. Another drop occurs in the early months of 2009.

From the second half of 2009, the three indices take their growth with a performance of the Sukuk index over the bonds index and the benchmark (Figure 3).

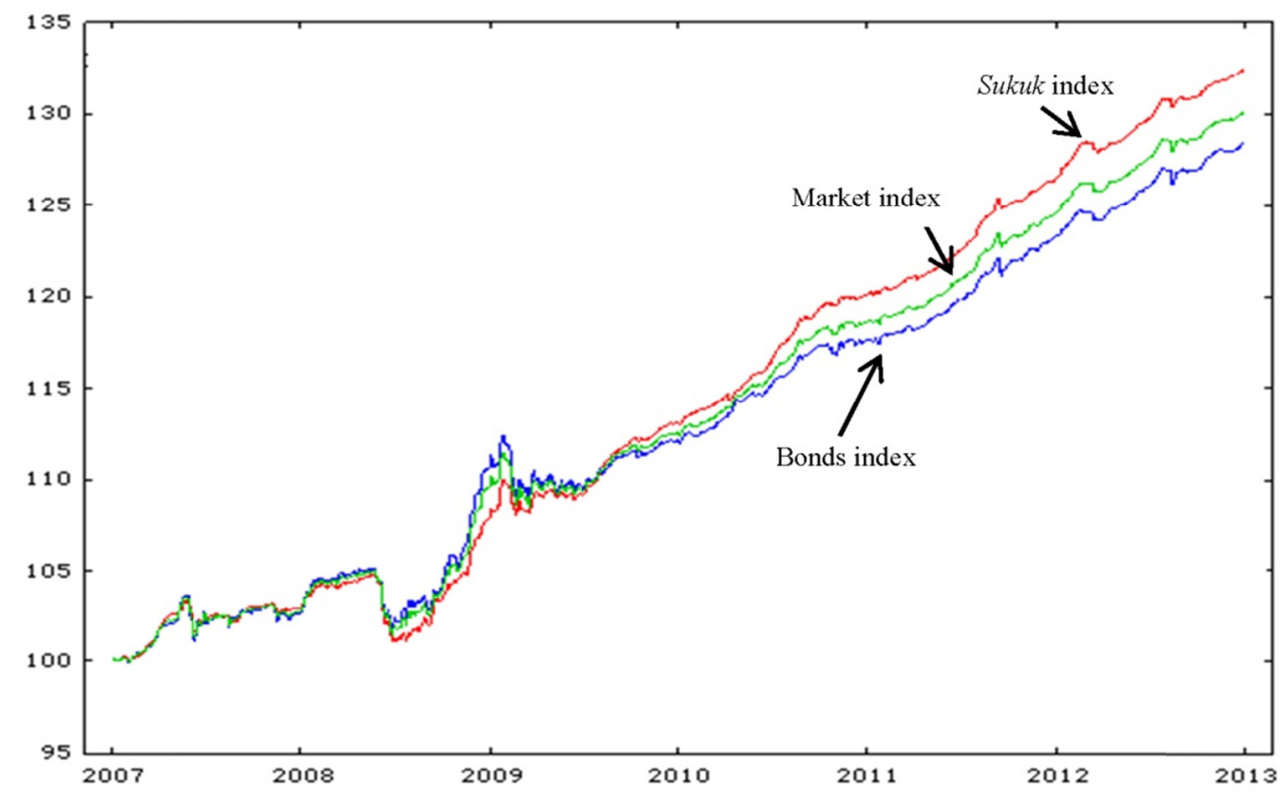

Figure 3. Sukuk, bonds and market indices evolution (base 100)

\subsection{Test of Significance of the Difference in the Portfolios' Mean Return}

\subsubsection{Variables Definition}

For this part of the study, we use the paired sample t-tests and in this goal we define the variables bellow:

- RPS1 represents the mean return of Sukuk portfolio P1 $1_{\text {Sukuk(all). }}$.

- RPB1 represents the mean return of bonds portfolio $\mathrm{P} 1_{\text {Bonds(all). }}$.

- RPS2 represents the mean return of Sukuk portfolio P2 2 Sukuk(3m-1y).

- RPB2 represents the mean return of bonds portfolio $\mathrm{P} 2_{\mathrm{Bond}(3 \mathrm{~m}-1 \mathrm{y})}$.

- RPS3 represents the mean return of Sukuk portfolio P $3_{\text {Sukuk }(1 y-3 y)}$.

- RPB3 represents the mean return of bonds portfolio $\mathrm{P} 3_{\mathrm{Bonds}(1 \mathrm{y}-3 \mathrm{y})}$.

- RPS4 represents the mean return of Sukuk portfolio $\mathrm{P} 4_{\text {Sukuk(3y-7y). }}$.

- RPB4 represents the mean return of bonds portfolio P4 $4_{\text {Bonds(3y-7y). }}$

- RPS4 represents the mean return of Sukuk portfolio $\mathrm{P} 5_{\operatorname{Sukuk}\left(7 \mathrm{y}^{+}\right)}$.

- RPB4 represents the mean return of bonds portfolio $\mathrm{P} 5_{\mathrm{Bonds}(7 \mathrm{y}+)}$.

The objective of these tests is to analyze the statistical significance of differences between the return means of different portfolios. The tests used are t-tests of paired samples. These tests aim to check if the return means of Sukuk and bonds portfolios are significantly different. The tests are, also, carried on the return means of different Sukuk portfolios and bonds portfolios regarding their maturity.

Results of t-tests between Sukuk and bonds portfolios are given in Table 2. These results are statistically insignificant. Only, results relating to Sukuk and bonds portfolios of 3 months to one year maturity are statistically significant. Then, we can conclude that there is a difference statistically significant between Sukuk and bonds portfolios having less than one year of maturity. 
Table 2. Paired sample t-test (Sukuk and bonds portfolios)

\begin{tabular}{|c|c|c|c|c|c|c|c|c|}
\hline & \multicolumn{5}{|c|}{ Paired Differences } & \multirow{3}{*}{$\mathrm{t}$} & \multirow{3}{*}{ df } & \multirow{3}{*}{$\begin{array}{c}\text { Sig. } \\
\text { (2-tailed) }\end{array}$} \\
\hline & \multirow[t]{2}{*}{ Mean } & \multirow{2}{*}{$\begin{array}{c}\text { Std. } \\
\text { Deviation }\end{array}$} & \multirow{2}{*}{$\begin{array}{l}\text { Std. Error } \\
\text { Mean }\end{array}$} & \multicolumn{2}{|c|}{$\begin{array}{l}95 \% \text { Confidence Interval of } \\
\text { the Difference }\end{array}$} & & & \\
\hline & & & & Lower & Upper & & & \\
\hline Pair 1 RPS1-RPB1 & 0.1243 & 8.2145 & 0.2135 & -0.2945 & 0.5432 & 0.582 & 1479 & 0.560 \\
\hline Pair 2 RPS2-RPB2 & -1.3402 & 1.4266 & $3.708^{\mathrm{E}}-02$ & -1.4129 & -1.2674 & -36.140 & & 0.000 \\
\hline Pair 3 RPS3-RPB3 & 0.1128 & 3.0626 & $7.961^{\mathrm{E}}-02$ & $-4.33^{\mathrm{E}}-02$ & 0.2690 & 1.417 & & 0.157 \\
\hline Pair 4 RPS4-RPB4 & $8.851^{\mathrm{E}}-02$ & 9.1979 & 0.2391 & -0.3805 & 0.5575 & 0.370 & & 0.711 \\
\hline Pair 5 RPS5-RPB5 & $7.568^{\mathrm{E}}-02$ & 21.6513 & 0.5628 & -1.0283 & 1.1796 & 0.134 & & 0.893 \\
\hline
\end{tabular}

Note: RPS1, RPB1 represent, for example, the mean return of $S u k u k$ portfolio $\mathrm{P} 1_{\text {Sukuk(all) }}$ and bonds portfolio $\mathrm{P} 1_{\mathrm{Bonds(all)}}$.

Results for paired samples t-tests regarding different Sukuk portfolios are given in Table 3. The results are statistically significant for only pairs including Sukuk portfolio of 3 months to one year of maturity $\mathrm{P} 2_{\mathrm{Sukuk}(3 \mathrm{~m}-1 \mathrm{y})}$. For the others pairs, results are statistically insignificant. From these results, we can conclude that there is a difference statistically significant between Sukuk portfolio having maturity less than one year (P2 $\left.2_{\operatorname{Sukuk}(3 \mathrm{~m}-1 \mathrm{y})}\right)$ and other Sukuk portfolios.

Table 3. Paired sample t-test (Sukuk portfolios)

\begin{tabular}{|c|c|c|c|c|c|c|c|c|}
\hline & \multicolumn{5}{|c|}{ Paired Differences } & \multirow{3}{*}{$\mathrm{t}$} & \multirow{3}{*}{ df } & \multirow{3}{*}{$\begin{array}{l}\text { Sig. } \\
\text { (2-tailed) }\end{array}$} \\
\hline & \multirow[t]{2}{*}{ Mean } & \multirow[t]{2}{*}{$\begin{array}{l}\text { Std. } \\
\text { Deviation }\end{array}$} & \multirow[t]{2}{*}{$\begin{array}{l}\text { Std. Error } \\
\text { Mean }\end{array}$} & \multicolumn{2}{|c|}{$\begin{array}{c}95 \% \text { Confidence } \\
\text { Interval of the } \\
\text { Difference }\end{array}$} & & & \\
\hline & & & & Lower & Upper & & & \\
\hline Pair 1 RPS1-RPS2 & 1.6328 & 9.0780 & 0.2360 & 1.1699 & 2.0956 & 6.919 & 1479 & 0.000 \\
\hline Pair 2 RPS1-RPS3 & $8.378^{\mathrm{E}}-02$ & 6.6849 & 0.1738 & -0.2571 & 0.4246 & 0.482 & & 0.630 \\
\hline Pair 3 RPS1-RPS4 & $3.378^{\mathrm{E}}-02$ & 2.8924 & $7.518^{\mathrm{E}}-02$ & -0.1441 & 0.1509 & 0.045 & & 0.964 \\
\hline Pair 4 RPS1-RPS5 & $-8.85^{\mathrm{E}}-02$ & 8.0340 & 0.2088 & -0.4982 & 0.3211 & -0.424 & & 0.672 \\
\hline Pair 5 RPS2- RPS3 & -1.5490 & 3.7673 & $9.793^{\mathrm{E}}-02$ & -1.7411 & -1.3569 & -15.818 & & 0.000 \\
\hline Pair 6 RPS2- RPS4 & -1.6294 & 8.3622 & 0.2174 & -2.0557 & -1.2030 & -7.496 & & 0.000 \\
\hline Pair 7 RPS2- RPS5 & -1.7213 & 16.6571 & 0.4330 & -2.5706 & -0.8719 & -3.975 & & 0.000 \\
\hline Pair 8 RPS3- RPS4 & $-8.04^{\mathrm{E}}-02$ & 5.9201 & 0.1539 & -0.3823 & 0.2215 & -0.523 & & 0.601 \\
\hline Pair 9 RPS3- RPS5 & -0.1723 & 14.4961 & 0.3768 & -0.9114 & 0.5668 & -0.457 & & 0.648 \\
\hline Pair10 RPS4- RPS5 & $-9.19^{\mathrm{E}}-02$ & 10.2495 & 0.2664 & -0.6145 & 0.4307 & -0.345 & & 0.730 \\
\hline
\end{tabular}

Table 4 gives results in the case of bonds portfolios. These results are statistically insignificant, and then we cannot conclude to a difference between return means of different bonds portfolios in this case.

Table 4. Paired sample t-test (bonds portfolios)

\begin{tabular}{|c|c|c|c|c|c|c|c|c|}
\hline & \multicolumn{5}{|c|}{ Paired Differences } & \multirow{3}{*}{$\mathrm{t}$} & \multirow{3}{*}{ df } & \multirow{3}{*}{$\begin{array}{l}\text { Sig. } \\
\text { (2-tailed) }\end{array}$} \\
\hline & \multirow[t]{2}{*}{ Mean } & \multirow[t]{2}{*}{$\begin{array}{l}\text { Std. } \\
\text { Deviation }\end{array}$} & \multirow[t]{2}{*}{$\begin{array}{l}\text { Std. Error } \\
\text { Mean }\end{array}$} & \multicolumn{2}{|c|}{$\begin{array}{l}95 \% \text { Confidence } \\
\text { Interval of the } \\
\text { Difference }\end{array}$} & & & \\
\hline & & & & Lower & Upper & & & \\
\hline Pair 1 RPB1-RPB2 & 0.1682 & 11.4917 & 0.2987 & -0.6022 & 0.9387 & 0.563 & 1479 & 0.573 \\
\hline Pair 2 RPB1-RPB3 & $7.230^{\mathrm{E}}-02$ & 9.2935 & 0.2416 & -0.5508 & 0.6954 & 0.299 & & 0.765 \\
\hline Pair 3 RPB1-RPB4 & $-3.24^{\mathrm{E}}-02$ & 5.5881 & 0.1453 & -0.4071 & 0.3422 & -0.223 & & 0.823 \\
\hline Pair 4 RPB1-RPB5 & -1.372 & 17.5791 & 0.4569 & -1.3157 & 1.0414 & -0.300 & & 0.764 \\
\hline Pair 5 RPB2- RPB3 & $-9.59^{\mathrm{E}}-02$ & 3.7563 & $9.764^{\mathrm{E}}-02$ & -0.3478 & 0.1559 & -0.983 & & 0.326 \\
\hline Pair 6 RPB2- RPB4 & -0.2007 & 12.1123 & 0.3148 & -1.0127 & 0.6114 & -0.637 & & 0.524 \\
\hline Pair 7 RPB2- RPB5 & -0.3054 & 28.1668 & 0.7322 & -2.1938 & 1.5830 & -0.417 & & 0.677 \\
\hline Pair 8 RPB3- RPB4 & -0.1047 & 9.8432 & 0.2559 & -0.7646 & 0.5552 & -0.409 & & 0.682 \\
\hline Pair 9 RPB3- RPB5 & -0.2095 & 26.3255 & 0.6843 & -1.9744 & 1.5555 & -0.306 & & 0.760 \\
\hline Pair10 RPB4- RPB5 & -0.1047 & 21.1570 & 0.5500 & -1.5231 & 1.3137 & -0.190 & & 0.849 \\
\hline
\end{tabular}

\subsection{Analysis of the Portfolios'Return Correlation}

The results of correlation tests on returns of the portfolios are shown in Tables 5, 6 and 7. Results of correlation tests of Sukuk portfolios (Table 5) indicate that returns of different portfolios are positively correlated. The correlation between Sukuk portfolio $\mathrm{P} 1_{\text {Sukuk(all) }}$ and Sukuk portfolios $\mathrm{P} 5_{\text {Sukuk }\left(7 \mathrm{y}^{+}\right)}$is estimated to 0.976 . The correlation between the first Sukuk portfolio and the fourth $\mathrm{P} 4_{\text {Sukuk(3y-7y) }}$ is about 0.948 . The correlation between $\mathrm{P} 1_{\text {Sukuk(all) }}$ and $\mathrm{P} 3_{\text {Sukuk(1y-3y) }}$ is 0.759 . Return of Sukuk portfolio having maturity of one year to three years 
$\left(\mathrm{P}_{\text {Sukuk(1y-3y) }}\right)$ and Sukuk portfolio of 3 to 7 years of maturity $\left(\mathrm{P}_{\text {Sukuk(3y-7y) }}\right)$ are significantly and positively correlated with a value 0.779 of correlation. The correlation is also significant and positive between Sukuk portfolios $\mathrm{P} 4_{\text {Sukuk(3y-7y) }}$ and $\mathrm{P} 5_{\text {Sukuk }\left(7 \mathrm{y}^{+}\right)}$with a value of 0.870 . Then, the correlation is positive and significant between different Sukuk portfolios while the value of correlation differs between different portfolios. Some portfolios have high correlation like portfolio of all maturities and portfolio of $7+$ years of maturity.

Table 5. Sukuk portfolios correlation

\begin{tabular}{lllllll}
\hline & & $\mathrm{P} 1_{\text {Sukuk(all) }}$ & $\mathrm{P} 2_{\text {Sukuk(3m-1y) }}$ & $\mathrm{P}_{\text {Sukuk(1y-3y) }}$ & $\mathrm{P} 4_{\text {Sukuk (3y-7y) }}$ & $\mathrm{P}_{\text {Sukuk(7y+) }}$ \\
\hline $\mathrm{P} 1_{\text {Sukuk(all) }}$ & Pearson & 1.000 & $* * 0.362$ & $* * 0.759$ & $* * 0.948$ & $* * 0.976$ \\
& Sig. (2-tailed) &. & 0.000 & 0.000 & 0.000 & 0.000 \\
& $\mathrm{~N}$ & 1480 & 1480 & 1480 & 1480 & 1480 \\
$\mathrm{P} 2_{\text {Sukuk(3m-1y) }}$ & Pearson & & 1.000 & $* * 0.474$ & $* * 0.350$ & $* * 0.304$ \\
& Sig. (2-tailed) & &. & 0.000 & 0.000 & 0.000 \\
& N & & 1480 & 1480 & 1480 & 1480 \\
$\mathrm{P} 3_{\text {Sukuk(1y-3y) }}$ & Pearson & & & 1.000 & $* * 0.779$ & $* * 0.650$ \\
& Sig. (2-tailed) & & & & 0.000 & 0.000 \\
& N & & & 1480 & 1480 & 1480 \\
$\mathrm{P} 4_{\text {Sukuk(3y-7y) }}$ & Pearson & & & & 1.000 & $* * 0.870$ \\
& Sig. (2-tailed) & & & & & 0.000 \\
& N & & & & 1480 & 1480 \\
$\mathrm{P} 5_{\text {Sukuk(7y+) }}$ & Pearson & & & & & 1.000 \\
& Sig. (2-tailed) & & & & & \\
& N & & & & & 1480 \\
\hline
\end{tabular}

Note: ** Correlation is significant at the 0.01 level (2-tailed).

Results of correlation tests of bonds portfolios (Table 6) indicate that returns of different portfolios are positively correlated. The correlation is high between bonds portfolio $\mathrm{P} 1_{\text {bonds(all) }}$ and bonds portfolios $\mathrm{P} 5_{\mathrm{Bonds}(7 \mathrm{y}+)}$ (with 0.950 value of correlation), $\mathrm{P} 4_{\mathrm{Bonds}(3 \mathrm{y}-7 \mathrm{y})}$ (with 0.901 value of correlation) and $\mathrm{P} 3_{\mathrm{Bonds}(1 \mathrm{y}-3 \mathrm{y})}$ (with 0.735 value of correlation). Return of bonds portfolio having maturity of one year to three years ( $\left.\mathrm{P} 3_{\mathrm{Bonds}(1 \mathrm{y}-3 \mathrm{y})}\right)$ and bonds portfolio of 3 to 7 years of maturity $\left(\mathrm{P}_{\mathrm{Bonds}(3 \mathrm{y}-7 \mathrm{y})}\right)$ are significantly and positively correlated with a value 0.730 of correlation. The correlation is also significant and positive between bonds portfolios $\mathrm{P} 4_{\mathrm{Bond}(3 \mathrm{y}-7 \mathrm{y})}$ and $\mathrm{P} 5_{\mathrm{Bond}(7 \mathrm{y}+)}$ with a value of 0.738 .

Table 6. Bonds portfolios correlation

\begin{tabular}{lllllll}
\hline & & $\mathrm{P} 1_{\text {Bonds(all) }}$ & $\mathrm{P} 2_{\text {Bonds(3m-1y) }}$ & $\mathrm{P} 3_{\text {Bonds(1y-3y) }}$ & $\mathrm{P} 4_{\text {Bonds(3y-7y) }}$ & $\mathrm{P} 5_{\text {Bonds(7y+) }}$ \\
\hline $\mathrm{P} 1_{\text {Bonds(all) }}$ & Pearson & 1.000 & $* * 0.534$ & $* * 0.735$ & $* * 0.901$ & $* * 0.950$ \\
& Sig. (2-tailed) &. & 0.000 & 0.000 & 0.000 & 0.000 \\
& $\mathrm{~N}$ & 1480 & 1480 & 1480 & 1480 & 1480 \\
$\mathrm{P} 2_{\text {Bonds(3m-1y) }}$ & Pearson & & 1.000 & $* * 0.757$ & $* * 0.487$ & $* * 0.423$ \\
& Sig. (2-tailed) & &. & 0.000 & 0.000 & 0.000 \\
& $\mathrm{~N}$ & 1480 & 1480 & 1480 & 1480 \\
$\mathrm{P} 3_{\text {Bonds(1y-3y) }}$ & Pearson & & & 1.000 & $* * 0.730$ & $* * 0.573$ \\
& Sig. (2-tailed) & &. & 0.000 & 0.000 \\
& N & & 1480 & 1480 & 1480 \\
$\mathrm{P} 4_{\text {Bonds(3y-7y) }}$ & Pearson & & & & 1.000 & $* * 0.738$ \\
& Sig. (2-tailed) & & & & 0.000 \\
& N & & & & 1480 & 1480 \\
$\mathrm{P} 5_{\text {Bonds(7y+) }}$ & Pearson & & & & & 1.000 \\
& Sig. (2-tailed) & & & &. \\
& N & & & & & 1480 \\
\hline
\end{tabular}

Note: ** Correlation is significant at the 0.01 level (2-tailed).

Concerning the correlation between Sukuk portfolios with bonds portfolios, the Table 7 shows the correlation coefficients between these two types of portfolios. The results indicate a positive correlation between Sukuk and bonds portfolios in each level of maturity with a significance level of $1 \%$. Thus, we can conclude that there is a significant correlation between returns of Sukuk and bonds portfolios. 
Table 7. Sukuk and bonds portfolios correlation

\begin{tabular}{|c|c|c|c|c|c|c|c|c|c|c|c|}
\hline & & $\mathrm{P} 1_{\text {Sukuk(all) }}$ & $\mathrm{P} 1_{\text {Bonds(a }}$ & $\mathrm{P} 2_{\text {Sukuk }(3 \mathrm{~m}-1}$ & $\mathrm{P} 2_{\text {Bonds }(3 \mathrm{~m}-1}$ & $\mathrm{P} 3_{\text {Sukuk }(1 \mathrm{y}-3}$ & $\mathrm{P} 3_{\text {Bonds }(1 \mathrm{y}-3}$ & $\mathrm{P} 4_{\text {Sukuk }(3 y-7}$ & P4 $4_{\text {Bonds }(3 y-7}$ & P5 $5_{\text {Sukuk(7y }}$ & P5 Bonds(7y \\
\hline \multirow[t]{3}{*}{$\mathrm{P} 1_{\text {Sukuk(all) }}$} & Pearson & 1.000 & $* * 0.739$ & $* * 0.362$ & $* * 0.494$ & $* * 0.759$ & $* * 0.631$ & $* * 0.948$ & $* * 0.638$ & $* * 0.976$ & $* * 0.672$ \\
\hline & Sig. & , & 0.000 & 0.000 & 0.000 & 0.000 & 0.000 & 0.000 & 0.000 & 0.000 & 0.000 \\
\hline & $\mathrm{N}$ & 1480 & 1480 & 1480 & 1480 & 1480 & 1480 & 1480 & 1480 & 1480 & 1480 \\
\hline \multirow[t]{3}{*}{$\mathrm{P} 1_{\text {Bonds(all) }}$} & Pearson & & 1.000 & $* * 0.305$ & $* * 0.534$ & $* * 0.629$ & $* * 0.735$ & $* * 0.709$ & $* * 0.901$ & $* * 0.703$ & $* * 0,950$ \\
\hline & Sig. & & , & 0.000 & 0.000 & 0.000 & 0.000 & 0.000 & 0.000 & 0.000 & 0.000 \\
\hline & $\mathrm{N}$ & & 1480 & 1480 & 1480 & 1480 & 1480 & 1480 & 1480 & 1480 & 1480 \\
\hline \multirow[t]{3}{*}{$\mathrm{P} 2_{\text {Sukuk }(3 \mathrm{~m}-1 \mathrm{y})}$} & Pearson & & & 1.000 & $* * 0.512$ & $* * 0.474$ & $* * 0.445$ & $* * 0.350$ & $* * 0.288$ & $* * 0.304$ & $* * 0.235$ \\
\hline & Sig. & & & , & 0.000 & 0.000 & 0.000 & 0.000 & 0.000 & 0.000 & 0.000 \\
\hline & $\mathrm{N}$ & & & 1480 & 1480 & 1480 & 1480 & 1480 & 1480 & 1480 & 1480 \\
\hline \multirow[t]{3}{*}{$\mathrm{P} 2_{\text {Bonds(3m-1y) }}$} & Pearson & & & & 1.000 & $* * 0.647$ & $* * 0.757$ & $* * 0.478$ & $* * 0.487$ & $* * 0.429$ & $* * 0.423$ \\
\hline & Sig. & & & & , & 0.000 & 0.000 & 0.000 & 0.000 & 0.000 & 0.000 \\
\hline & $\mathrm{N}$ & & & & 1480 & 1480 & 1480 & 1480 & 1480 & 1480 & 1480 \\
\hline \multirow[t]{3}{*}{$\mathrm{P} 3_{\text {Sukuk }(1 \mathrm{y}-3 \mathrm{y})}$} & Pearson & & & & & 1.000 & $* * 0.762$ & $* * 0.779$ & $* * 0.609$ & $* * 0.650$ & $* * 0.514$ \\
\hline & Sig. & & & & & , & 0.000 & 0.000 & 0.000 & 0.000 & 0.000 \\
\hline & $\mathrm{N}$ & & & & & 1480 & 1480 & 1480 & 1480 & 1480 & 1480 \\
\hline \multirow[t]{3}{*}{ P3 3 Bonds(1y-3y) } & Pearson & & & & & & 1.000 & $* * 0.632$ & $* * 0.730$ & $* * 0.553$ & $* * 0.573$ \\
\hline & Sig. & & & & & & , & 0.000 & 0.000 & 0.000 & 0.000 \\
\hline & $\mathrm{N}$ & & & & & & 1480 & 1480 & 1480 & 1480 & 1480 \\
\hline \multirow[t]{3}{*}{ P4 $4_{\text {Sukuk(3y-7y) }}$} & Pearson & & & & & & & 1.000 & $* * 0.693$ & $* * 0.870$ & $* * 0.617$ \\
\hline & Sig. & & & & & & & , & 0.000 & 0.000 & 0.000 \\
\hline & $\mathrm{N}$ & & & & & & & 1480 & 1480 & 1480 & 1480 \\
\hline \multirow[t]{3}{*}{ P4 $4_{\text {Bonds(3y-7y) }}$} & Pearson & & & & & & & & 1.000 & $* * 0.628$ & $* * 0.738$ \\
\hline & Sig. & & & & & & & & , & 0.000 & 0.000 \\
\hline & $\mathrm{N}$ & & & & & & & & 1480 & 1480 & 1480 \\
\hline \multirow[t]{3}{*}{$\mathrm{P} 5_{\text {Sukuk }\left(7 \mathrm{y}^{+}\right)}$} & Pearson & & & & & & & & & 1.000 & $* * 0.663$ \\
\hline & Sig. & & & & & & & & & & 0.000 \\
\hline & $\mathrm{N}$ & & & & & & & & & & 1480 \\
\hline \multirow[t]{3}{*}{$\mathrm{P} 5_{\text {Bonds }(7 \mathrm{y}+)}$} & Pearson & & & & & & & & & & 1.000 \\
\hline & Sig. & & & & & & & & & & , \\
\hline & $\mathrm{N}$ & & & & & & & & & & 1480 \\
\hline
\end{tabular}

Note: $* *$ Correlation is significant at the 0.01 level (2-tailed).

\section{Conclusion}

This research has compared the performance of Sukuk and bonds portfolios using a series of indices in the Malaysian Sukuk and bonds market. Indeed, we use the indices of the series TR BPAM ALL BOND INDEX reflecting the performance of Sukuk and bonds market in Malaysia for the period from 2007 to 2012 . We first addressed the significance of the difference in the portfolios' mean return. Secondly, we addressed the portfolios' return correlation. For the issue of the significance of the difference in the portfolios' mean return, the results of paired sample t-tests show that there is a difference statistically significant, only, between Sukuk and bonds portfolios having less than one year of maturity. The results of correlation indicate a significant and positive correlation between returns of Sukuk and bonds portfolios. This study complements the studies concerned with the comparison of performance of Sukuk and bonds. The particularity of this study is that we work on Sukuk and bond portfolios based on indices reflecting the performance of the Malaysian bond and Sukuk market instead of using a small sample of individual Sukuk. In addition, analysis of Sukuk index in this same paper reveals that it outperforms its conventional counterpart. Overall, our results agree with those of some studies confirming that Sukuk perform as bonds given the positive correlation between these two financial instruments.

\section{References}

Accounting and Auditing Organization for Islamic Financial Institutions (AAOIFI). (2008). Resolution on Sukuk. Retrieved from http://www.aaoifi.com/aaoifi_sb_sukuk_Feb2008_Eng.pdf

Ariff, M., \& Safari, M. (2012). Are Sukuk Securities the Same as Conventional Bonds? Afro Eurasian Studies, 1(1), $101-125$.

Cakir, S., \& Raei, F. (2007). Sukuk vs conventional bonds: Is there a difference in value at risk? Working Paper. Washington DC: International monetary fund.WP/07/237.

Fathurahman, H., \& Fitriati, R. (2013). Comparative Analysis of Return on Sukuk and Conventional Bonds. American Journal of Economics, 3(3), 159-163. Retrieved from http://article.sapub.org/pdf/10.5923.j.economics.20130303.05.pdf 
Fitriya. (2012). The impact of Islamic debt on firm performance. $\mathrm{PhD}$ thesis, Waikato University.

Godlewski, C., Turk-Arsis, R., \& Weill, L. (2013). Sukuk vs conventional bonds: A stock market perspective. Journal of Comparative Economics, 41, 745-761. http://dx.doi.org/10.1016/j.jce.2013.02.006

Hassan, K. A. (2012). Comparison between Sukuk and conventional bonds: Value at risk approach. Master thesis, Westminster University, UK. http://dx.doi.org/10.2139/ssrn.2215194

Lahsasna, A., \& Lin, L. S. (2012). Issues in islamic capital markets: Islamic bond/Sukuk. In 3rd International conference on Business and Economic Research. Proceeding. 12-13 March 2012. Bandung, Indonesia.

Oakely, D. (2011). Sukuk: Market shows resilience. Retrieved from http://www.ft.com/intl/cms/s/0/31f2629e-7aa1-11e0-8762-0144feabdc0.html\#axzz1d6ANxDgU

Ramasamy, R., Munisamy, S., \& Helmi, M. H. M. (2011). Relative risk of Islamic sukuk over government and conventional bonds. Global Journal of Management and Business Research, 11(6), 4-12.

Tahmoures, A. A. (2013). Compare and contrast Sukuk (Islamic Bonds) with conventional bonds, Are they compatible? The Journal of Global Business Management, 9(1), 44-52. Retrieved from http://www.jgbm.org/page/5\%20Tahmoures\%20A\%20\%20Afshar.pdf

Thomas, A. (2007). Malaysia's importance to the Sukuk market: March 2007 report. American Journal of Islamic Finance.

Zakaria, N. B., Isa, M. A. M., \& Abidin, R. A. Z. (2012). The construct of Sukuk, rating and default risk. Procedia-Social and Behavioral Sciences, 65, 662-667. http://dx.doi.org/10.1016/j.sbspro.2012.11.181

Zawya, S. (2012). Retrieved from http://www.zawya.com/sukuk/

Zin, M. Z. M., Sakat, A. A., Ahmad, N. A., Nor, M. R. M., Bhari, A., Ishak, S., \& Jamain, M. S. (2011). The effectiveness of Sukuk in Islamic finance market. Australian Journal of Basic and Applied Sciences, 5(12), $472-478$.

\section{Notes}

Note 1. Sharia is the moral code and religious law of Islam.

Note 2. Shell MDS (Malaysia) is the owner and operator of the Shell Middle Distillate Synthesis (SMDS) plant in Bintulu, Sarawak.

\section{Copyrights}

Copyright for this article is retained by the author(s), with first publication rights granted to the journal.

This is an open-access article distributed under the terms and conditions of the Creative Commons Attribution license (http://creativecommons.org/licenses/by/3.0/). 